\title{
PENGARUH POINT OF PURCHASE TERHADAP KEPUTUSAN PEMBELIAN TIDAK TERENCANA DI CARREFOUR TAMINI SQUARE
}

\author{
Ahmad Fajar Novarianto 1, Firman Kurniawan ${ }^{2}$, Irwansyah ${ }^{3}$, Poppy Ruliana 4 \\ STIKOM - Interstudi ${ }^{1}$, Ilmu Komunikasi Pascasarjana Universitas Indonesia ${ }^{2}$, Ilmu \\ Komunikasi Universitas Indonesia ${ }^{3}$, STIKOM - Interstudi 4 \\ ryan.novarianto@gmail.com ${ }^{1}$, firmankurniawan@yahoo.com ${ }^{2}$, ironesyah@gmail.com ${ }^{3}$, \\ poppyruliana30@gmail.com ${ }^{4}$
}

\begin{abstract}
Problems in this study regarding the Effect of Point of Purchase on Unplanned Purchasing Decisions (Effect of In Store Media, Signage, and Display on Unplanned Buying Decisions in Carrefour Tamini Square). The purpose of this study is to prove and find out whether there is an effect of point of purchase either simultaneously or partially on unplanned purchase decisions. The theory used is marketing communication which can be defined as marketing activities using communication techniques that aim to provide information to the audience so that the company's goals are achieved, namely an increase in revenue from the use of services or purchase of products offered. (Kennedy and Soemanegara, 2006: 5). The research method uses surveys for data collection and has the results of using a questionnaire with data processing techniques using SPSS. From the results of the regression equation produced that simultaneously, the point of purchase has a significant influence on unplanned purchase decisions of 67.3 percent and the remaining 32.7 percent is explained by other factors not used as variables in this study. While partially, only signage and displays have a significant influence on unplanned purchasing decisions. In store media does not have a significant influence on unplanned buying decisions. From the results of the study it is recommended that Carrefour Tamini Square improve the quality of signage, because it is the point of purchase dimension that most influences on unplanned buying decisions. Then make a display that follows the trend, or thematic displays with different concepts and tend to be strange or unique, because the more strange and unique a display, the more it will cause consumer curiosity that will be able to end with purchases that were not planned before.
\end{abstract}

Keywords: Point of Purchase; Unplanned Purchasing Decisions.

\begin{abstract}
ABSTRAK
Permasalahan dalam penelitian ini mengenai Pengaruh Point of Purchase Terhadap Keputusan Pembelian Tidak Terencana (Pengaruh In Store Media, Signage, dan Display Terhadap Keputusan Pembelian Tidak Terencana di Carrefour Tamini Square). Tujuan Penelitian ini untuk membuktikan dan mengetahui apakah terdapat pengaruh point of purchase baik secara simultan atau parsial terhadap keputusan pembelian tidak terencana. Teori yang digunakan adalah komunikasi pemasaran yang dapat didefinisikan sebagai kegiatan pemasaran dengan menggunakan teknik-teknik komunikasi yang bertujuan untuk memberikan informasi kepada khalayak agar tujuan perusahaan tercapai, yaitu terjadinya peningkatan pendapatan atas penggunaan jasa atau pembelian produk yang ditawarkan. (Kennedy dan Soemanegara, 2006:5). Metode penelitian menggunakan survey untuk pengumpulan data dan memiliki hasil menggunakan kuesioner dengan teknik pengolahan data menggunakan SPSS. Dari hasil
\end{abstract}


persamaan regresi dihasilkan bahwa secara simultan, point of purchase mempunyai pengaruh yang signifikan terhadap keputusan pembelian tidak terencana sebesar 67.3 persen dan 32.7 persen sisanya dijelaskan oleh faktor-faktor lain yang tidak dijadikan variabel dalam penelitian ini. Sedangkan secara parsial, hanya signage dan display yang mempunyai pengaruh signifikan terhadap keputusan pembelian tidak terencana. In store media tidak mempunyai pengaruh yang signifikan terhadap keputusan pembelian tidak terencana. Dari hasil penelitian maka disarankan Carrefour Tamini Square meningkatkan kualitas signage, karena hal tersebut adalah dimensi point of purchase yang paling berpengaruh terhadap keputusan pembelian tidak terencana. Kemudian membuat display yang mengikuti trend, atau display tematik dengan konsep yang berbeda dan cenderung aneh atau unik, karena semakin aneh dan unik sebuah display, maka akan semakin menimbulkan rasa penasaran konsumen yang akan bisa berakhir dengan pembelian yang tidak direncanakan sebelumnya.

Kata kunci : Point of Purchase; Keputusan Pembelian Tidak Terencana.

\section{PENDAHULUAN}

Kebutuhan konsumen yang semakin berkembang selalu diikuti oleh peningkatan variasi produk yang ditawarkan produsen. Pada kenyataannya tidak semua konsumen mengetahui bagaimana cara untuk memenuhi kebutuhannya atau tidak menyadari adanya produk yang mampu memenuhi kebutuhannya. Meskipun telah mengetahui informasi (well informed), belum tentu konsumen akan memilih atau membeli kembali produk perusahaan (karena belum bersedia membeli sekarang, adanya produk lain yang sejenis, adanya barang pengganti, merasa harga terlalu mahal, kurang dapat memenuhi kebutuhan, dan sebagainya). (Budiarto 1993:124).

Hal ini dipengaruhi oleh pertumbuhan ekonomi Indonesia yang mempengaruhi gaya hidup masyarakat, khususnya segmen menengah. Gaya hidup modern yang berkembang saat ini tidak lepas dari 'naik kelas'-nya masyarakat rendah ke menengah. Kebiasaan berbelanja juga bergeser, hingga pasar modern selalu diminati masyarakat. Konsumen lebih memilih belanja di toko ritel dengan alasan tempat yang lebih bersih dan nyaman, harga yang pasti, bukti pembelian yang jelas, dan berbagai promosi yang ditawarkan. Hal ini didukung peningkatan jumlah pengunjung Carrefour sebagai salah satu toko ritel yang naik menjadi 17.000 - 20.000 pengunjung per hari saat Carrefour memberlakukan program diskon 10 persen disetiap gerai nya. (https://finance.detik.com/beritaekonomi-bisnis/d-1782164/gaya-hidup-berubah-masyarakat-lebih-pilih-pasarmodern).

Menurut hasil riset AC Nielsen di tahun 2013, dikatakan bahwa 85 persen konsumen membuat keputusan memilih produk atau merek di dalam toko. Hasil riset ini didukung oleh penelitian yang dilakukan oleh Shimp (2003:335) yang mengatakan bahwa 60 persen konsumen adalah konsumen yang membeli barang tanpa rencana terlebih dahulu dikarenakan tertarik akan suatu hal seperti merek, kelebihan produk, dan hal lainnya. Tingkah laku konsumen menunjukkan bahwa para calon pembeli membuat keputusan 
pembelian tidak hanya berdasarkan daya tarik fungsional, tetapi juga emosional. Dimana daya tarik fungsional yang dimaksud berupa harga murah, sedangkan daya tarik emosional berupa lay out gerai dan pemajangan barang atau display yang menarik yang dapat memudahkan dan membuat konsep nyaman, serta mendorong pembeli untuk melakukan tindakan pembelian tidak terencana.

Pengetahuan tentang perilaku konsumen dalam mengambil keputusan saat berbelanja sangat penting diketahui oleh pengelola toko ritel agar dapat memenangkan kompetisi. Salah satu upaya untuk memenangkan kompetisi adalah dengan cara memperhatikan komunikasi pemasaran. Komunikasi pemasaran adalah sarana dimana perusahaan berusaha menginformasikan, membujuk, dan mengingatkan konsumen secara langsung maupun tidak langsung tentang produk dan merek yang dijual. Komunikasi pemasaran mempresentasikan "suara" perusahaan dan mereknya serta merupakan sarana di mana perusahaan dapat membuat dialog dan membangun hubungan dengan konsumen. (Shimp, 2003:4). Semenik et al (2012:621) menjelaskan ada beberapa alat promosi atau material komunikasi pemasaran yaitu Advertising, Sales Promotion, Point Of Purchase, Event Sponsorship, Produk Placement, Branded Entertainment, Direct Marketing, Personal Selling, Public Relation, Influencer Marketing, Corporate Advertising, Social Media, dan Word Of Mouth (WOM). Dari beberapa material komunikasi pemasaran tersebut, jika kita merujuk kepada toko ritel, maka yang sangat berpengaruh adalah point of purchase (POP).

Point of purchase (POP) adalah media promosi produk yang berada tepat di ujung tombak penjualan, karena langsung berhadapan dengan konsumen. Point of purchase (POP), kadang disebut juga Visual Merchandising, dapat dipasang di deretan produk yang ada di etalase atau area kasir, untuk mengingatkan konsumen terhadap keunggulan produk, menambahkan promosi interaktif seperti polling atau take-and-go item, dan sebagainya. Point of purchase (POP) menjadi penting karena merek bertambah banyak, sehingga semakin banyak produk yang saling berebut perhatian konsumen. Jika promosi mengingatkan calon konsumen akan merek atau brand, maka POP bekerja dengan mengikuti kebiasaan konsumen yang cenderung membeli produk berdasarkan dorongan impulsif atau perasaan.

Top Brand dalam Top Brand Survey (2017), menunjukkan bahwa Carrefour merupakan salah satu toko ritel tempat favorit berbelanja aneka kebutuhan rumah tangga dalam kategori hypermarket. Carrefour sudah hadir di Indonesia sejak 1998 dengan konsep one stop shopping. Carrefour dengan konsep one stop shopping telah memiliki area khusus untuk mom \& baby, electronic pro, fashion, home living, fresh, bread shop dan juga area groceries. Hingga saat ini, Carrefour telah beroperasi di lebih dari 100 gerai yang tersebar di 38 kota atau kabupaten di Indonesia. Di Jakarta, Carrefour memiliki 26 gerai dengan beberapa diantaranya merupakan gerai yang tidak menyatu dengan pusat perbelanjaan lain atau berdiri sendiri. 
Berdasarkan penjelasan yang telah dipaparkan di atas, terlihat jelas pentingnya point of purchase (POP) karena penentuan sebuah produk akan dibeli atau tidak terjadi pada saat di dalam toko, maka peneliti tertarik untuk mengangkat judul penelitian mengenai "Pengaruh Point of Purchase dalam Pembelian Tidak Terencana". Peneliti memilih Carrefour Tamini Square sebagai lokasi penelitian dengan pertimbangan bahwa Carrefour Tamini Square telah menjadi lokasi berbelanja yang difavoritkan oleh banyak individu dan keluarga karena kelengkapan produk serta kenyamanan yang ditemukan di dalamnya, di samping itu, tidak seperti pengunjung gerai Carrefour lain yang berdiri sendiri yang memang sudah memiliki rencana belanja sebelumnya, pengunjung Carrefour Tamini Square adalah para pengunjung yang kebetulan mampir dan tidak mempunyai rencana belanja sebelumnya, sehingga peran dari point of purchase (POP) dirasa lebih efektif.

\section{TINJAUAN PUSTAKA}

\section{Komunikasi Pemasaran}

Komunikasi pemasaran dapat didefinisikan sebagai kegiatan pemasaran dengan menggunakan teknik-teknik komunikasi yang bertujuan untuk memberikan informasi kepada khalayak agar tujuan perusahaan tercapai, yaitu terjadinya peningkatan pendapatan atas penggunaan jasa atau pembelian produk yang ditawarkan. (Kennedy dan Soemanegara, 2006:5)

Menurut Bussiness Dictionary, komunikasi pemasaran adalah suatu pesan-pesan promosi yang terkoordinasi dan dikirim melalui satu atau lebih saluran komunikasi seperti media cetak, radio, televisi, surat, dan penjualan secara personal. Sedangkan menurut Kotler dan Keller (2016:27), komunikasi pemasaran adalah sarana yang digunakan untuk menginformasikan, mempersuasi, dan mengingatkan konsumen, baik secara langsung maupun tidak langsung, mengenai produk-produk dan merek-merek yang dijual, Shimp (2003:4) mengemukakan bahwa komunikasi pemasaran atau marketing communication adalah aspek penting dalam keseluruhan misi pemasaran serta penentu suksesnya pemasaran. Komunikasi pemasaran dapat dipahami dengan menguraikan dua unsur pokoknya, yaitu komunikasi dan pemasaran. Komunikasi adalah proses di mana pemikiran dan pemahaman disampaikan antar individu atau antara organisasi dengan individu. Pemasaran adalah sekumpulan kegiatan dimana perusahaan dan organisasi lainnya mentransfer nilai-nilai (pertukaran) antara mereka dengan pelanggannya.

\section{Point of Purchase}

Semenik et al (2012:622) mendefinisikan Point of purchase (POP) sebagai bahan atau material yang digunakan untuk menarik perhatian pembeli terhadap merek, menginformasikan manfaat utama merek, atau menampilkan informasi harga. POP juga menampilkan penawaran harga atau promosi penjualan konsumen lainnya. Sedangkan 
Shimp (2003:320) menjelaskan bahwa POP adalah waktu yang ideal untuk berkomunikasi dengan para konsumen karena inilah saatnya berbagai keputusan pemilihan produk dan merek dibuat. Inilah saat dan tempat dimana seluruh elemen jual beli (konsumen, uang, dan produk) hadir bersama-sama. Para pemasar yang cerdas berpromosi menyadari bahwa lingkungan toko adalah peluang terbaik yang terakhir untuk menampilkan sesuatu yang berbeda. Para pemasar berupaya mempengaruhi berbagai keputusan pembelian pada poin pembelian dengan menggunakan beragam tampilan atau pajangan iklan (display), tanda-tanda, serta perangkat komunikasi lainnya. Material POP mencakup beragam tipe tanda, penunjuk bergerak, spanduk, gantungan di rak-rak dengan tulisan (shelf talker), boneka atau manekin mekanis, lampu-lampu, cermin, repro produk dari plastik, unit pengecekan, pedagang yang berjajar, posterposter dinding, beserta item-item lainnya.

Point of Purchase Advertising Institute (POPAI) dalam First Annual POP Buyers Survey, 1993, mengkategorikan POP menjadi tiga kategori, yaitu: (1) POP Permanen. Material POP permanen mencakup display dan tanda-tanda yang sengaja digunakan dalam jangka waktu enam bulan atau lebih. (2) POP Temporer. Material POP temporer mencakup display dan tanda-tanda yang sengaja digunakan kurang dari enam bulan. (3) Media in Store. Media In Store mencakup material iklan dan promosi seperti radio POP (program radio in store yang membawakan iklan komersil), iklan yang tertempel di kereta belanja, tulisan di rak pajangan (berupa iklan yang diletakkan di rak-rak toko yang mempromosikan merek), serta mesin penjual kupon. Juga perusahaan pihak ketiga (misalnya perusahaan lain selain produsen merek dan pengecer) menyelenggarakan media in store tersebut.

Nyken Widyastuti dan Retno Tanding Suryandari (2004) dalam jurnal Pengaruh Point Of Purchase Dalam Perilaku Pembelian Konsumen menyederhanakan perangkat POP menjadi tiga, yaitu :

\section{In Store Media}

Nyken Widyastuti dan Retno Tanding Suryandari (2004), menyatakan bahwa in store media merupakan perangkat point of purchase (POP) yang paling baru. Di mana perangkat atau variabel point of purchase (POP) tersebut yang memanfaatkan video atau radio di dalam toko. Salah satu komponen utama yang digunakan dalam in store media ini adalah musik yang memainkan peran penting dalam pembuatan keputusan pembelian konsumen. Oleh karena itu, musik memiliki peranan penting dalam mempengaruhi konsumen melakukan pembelian.

Terence A. Shimp (2003:487) menyatakan bahwa musik, jingle, musik latar, nada-nada popular, dan arasemen klasik digunakan untuk menarik perhatian, menyalurkan pesanpesan penjualan, menentukan emosional untuk iklan dan mempengaruhi suasana hati para pendengar. Sedangkan Ujang Sumarwan (2011:377) menyatakan bahwa musik merupakan bagian dari tata suara yang akan menimbulkan suasana yang menyenangkan 
bagi konsumen, sehingga mereka bisa lebih lama berbelanja dan membeli barang. Dengan demikian, musik memiliki pengaruh terhadap keputusan konsumen dalam melakukan pembelian.

Musik dapat diperdengarkan dengan tempo cepat atau lambat. Namun keduanya memiliki pengaruh yang berbeda dalam mempengaruhi keputusan pembelian konsumen. Menurut penelitian Blackwell dan Miniard (1995) dalam Ujang Sumarwan (2011:377) menyatakan bahwa musik dalam tempo lambat yang diperdengarkan di supermarket menyebabkan waktu berbelanja lebih lama dan jumlah uang yang dikeluarkan lebih banyak dibandingkan jika diperdengarkan musik dengan tempo yang lebih cepat. Jadi, musik dapat diperdengarkan dengan tempo cepat maupun lambat. Namun, musik dengan tempo yang lambat lebih banyak mempengaruhi konsumen dalam melakukan pembelian.

\section{Signage}

Signage merupakan perangkat point of purchase (POP) yang berupa tanda-tanda tentang suatu produk yang berada di dalam toko seperti informasi harga, keunggulan suatu produk tertentu dan lain-lain. Dengan informasi tersebut, konsumen akan lebih mudah mendapat informasi dan mencocokkan dengan barang yang dibutuhkan. Signage terdiri dari beberapa jenis, yaitu poster yang merupakan gambar-gambar untuk menarik perhatian konsumen di dalam toko dan menunjang penataan barang lebih memikat. Label harga, adalah informasi tentang harga suatu produk, yang membuat konsumen dapat mempertimbangkan dengan mudah untuk membeli. Papan promosi, digunakan untuk mengumumkan sesuatu. Biasanya diletakkan di depan toko. Papan petunjuk letak produk, digunakan untuk memudahkan konsumen dalam mendapatkan produk yang diinginkan. Selain itu, papan petunjuk juga digunakan sebagai salah satu bentuk komunikasi yaitu promosional sign, locational sign, dan institutional sign.

\section{Display}

Sopiah dan Syihabudhin (2008) menyatakan bahwa display adalah usaha yang dilakukan untuk menata barang yang mengarahkan pembeli agar tertarik untuk melihat dan membeli. Display merupakan pemajangan atau tata letak barang dagangan untuk menarik minat beli konsumen agar terciptanya pembelian. Bob Faster (2008) menyatakan bahwa Display adalah keinginan membeli sesuatu, yang tidak didorong oleh seseorang tapi didorong oleh daya tarik, ataupun oleh penglihatan, ataupun oleh perasaan lainnya. Dengan demikian hanya dengan melihat barang dagangan disertai dengan penataan barang yang bagus maka konsumen akan tertarik serta memudahkan konsumen dalam memilih barang yang diinginkan.

Bentuk-bentuk display menurut Devi Puspitasari (2006), yaitu window display yang merupakan pemajangan barang dagangan di etalase atau jendela kegiatan usaha. Tujuan window display adalah untuk menarik minat konsumen sekaligus menjaga keamanan barang dagangan. Window display hanya memperlihatkan barang dagangan yang 
ditawarkan saja, tanpa dapat disentuh oleh konsumen, sehingga pengamanan menjadi lebih mudah. Bila konsumen ingin mengetahui lebih lanjut, maka ia dipersilahkan untuk lebih masuk dan memperjelas pengamatannya. Interior display yang merupakan pemajangan barang dagangan di dalam toko. Interior display banyak dipergunakan untuk barang-barang yang sudah dikenal luas oleh masyarakat. Eksterior display yang merupakan pemajangan barang dagangan di tempat tertentu di luar kegiatan usaha yang biasa digunakan. Pemajangan sistem ini banyak digunakan untuk promosi barang, pengenalan produk baru, penjualan istimewa seperti cuci gudang, discount dan sejenisnya.

\section{Pembelian Tidak Terencana}

Tingkah laku konsumen menunjukkan bahwa para calon pembeli membuat keputusan pembelian tidak hanya berdasarkan daya tarik fungsional, tetapi juga emosional. Dimana daya tarik fungsional yang dimaksud berupa harga murah, sedangkan daya tarik emosional berupa lay out gerai dan pemajangan barang atau display yang menarik yang dapat memudahkan dan membuat konsep nyaman, serta mendorong pembeli untuk melakukan tindakan pembelian tidak terencana. Akibatnya tidak sedikit toko ritel modern yang saat ini menggunakan daya tarik emosional. Fenomena tersebut didukung dengan pernyataan Mowen dan Minor (2002:65) yang mengungkapkan bahwa pembuat iklan seringkali menggunakan tampilan emosi dan mempengaruhi konsumen. Karena perspektif pengalaman atas pembelian konsumen menyatakan bahwa untuk beberapa hal konsumen tidak melakukan pembelian sesuai dengan proses pengambilan keputusan yang rasional. Namun mereka membeli produk atau jasa tertentu untuk memperoleh kesenangan, menciptakan fantasi, atau perasaan emosi saja.

Terkait dengan pembelian tidak terencana, Mowen dan Minor (2002:65) menjelaskan bahwa tindakan membeli yang dilakukan tanpa adanya niat membeli yang terbentuk sebelum memasuki toko. Selanjutnya, Berman dan Evans (dalam Sujana, 2005:15) menyatakan bahwa pembelian tidak terencana merupakan kondisi yang tercipta dari ketersediaan barang dalam jumlah dan jenis yang sangat variatif sehingga menimbulkan banyaknya pilihan dalam proses belanja konsumen, disamping itu, konsumen dalam proses belanjanya, keputusan yang diambil untuk membeli suatu barang adalah yang sebelumnya tidak tercantum dalam daftar belanja (out of purchase list), keputusan ini muncul begitu saja terstimulasi oleh variasi produk (assortment) serta tingkat harga barang yang ditawarkan. Definisi lain menurut Schiffman dan Kanuk (2008:511) pembelian tidak terencana merupakan keputusan yang emosional atau menurut desakan hati, emosi dapat menjadi sangat kuat dan kadangkala berlaku sebagai dasar dari motif pembelian yang dominan. Konsumen cenderung melakukan pembelian tanpa berpikir panjang akan kegunaan barang dibeli, yang penting konsumen merasa terpuaskan, sehingga emosi menjadi merupakan hal yang berperan sebagai dasar pembelian suatu produk. 
Berdasarkan jurnal Semuel (2005), karakteristik produk yang mampu mempengaruhi pembelian tidak terencana antara lain memiliki harga yang murah sehingga konsumen tidak perlu berpikir untuk menghitung budget yang dikeluarkan, adanya sedikit kebutuhan terhadap produk tersebut, siklus kehidupan produknya pendek (produk yang langsung habis digunakan), kemudian ukurannya kecil atau ringan serta mudah disimpan karena biasanya produk seperti ini dianggap murah dan tidak terlalu membebani keranjang atau kereta belanjanya.

\section{Hubungan Antara Point of Purchase (POP) dan Pembelian Tidak Terencana}

Point of purchase (POP) merupakan bagian dari media yang digunakan dalam media lini bawah (below the line) sebagai alat bantu promosi penjualan (Kasali, 1992:142).

Hal ini tentunya mampu meningkatkan volume penjualan dan keuntungan bagi perusahaan ritel tersebut. Sebagaimana yang dikatakan Kasali (1992:146) bahwa point of purchase merupakan serangkaian display untuk mendukung penjualan perusahaan. Ketika berada di dalam sebuah toko, sering kali kita pada akhirnya membeli barang yang sebenarnya tidak menjadi barang utama yang ingin kita beli. Bisa jadi karena barang tersebut sedang didiskon, atau kita tergiur oleh promosi dan fitur-fitur yang disajikan melalui banyak tulisan yang ada di dalam toko. Nah, ketika kita melakukan pembelian tak terencana tersebut, secara tidak langsung kita telah terpengaruh oleh point of purchase yang ada di dalam toko itu.

Kasali (1992:146) mengemukakan bahwa ada sejumlah besar konsumen yang membeli di tempat tanpa berpikir sebelumnya. Pernyataan ini didukung dengan pendapat Shimp (2003:334), bahwa salah satu keberhasilan promosi dengan point of purchase yaitu meningkatkan rangsangan konsumen untuk melakukan keputusan pembelian di dalam toko.

\section{METODE PENELITIAN}

Jenis penelitian ini menggunakan metode kuantitatif yang berkarakter probablistik menggunakan analisis regresi berganda. Metode yang digunakan untuk menganalisis data adalah regresi linier berganda dengan serangkaian uji instrumen dan uji asumsi klasik. Menurut Sugiyono (2011:7), metode penelitian kuantitatif dapat diartikan sebagai metode penelitian yang berlandaskan pada filsafat positivisme, digunakan untuk meneliti pada populasi atau sampel tertentu.

Teknik pengambilan sampel pada umum nya dilakukan secara acak (random sampling), pengumpulan data menggunakan instrumen penelitian, analisis data bersifat kuantitatif/statistik dengan tujuan untuk menguji hipotesis yang telah ditetapkan. Sedangkan seperti yang dinyatakan oleh Burns dan Bush (dalam Mangkunegara, 2011) 
bahwa penelitian kuantitatif adalah penelitian yang membutuhkan penggunaa struktur pertanyaan dimana pilihan-pilihan jawabannya telah disediakan dan membutuhkan banyak responden. Format yang didapat adalah berupa angka atau numerik. Menurut Husein Umar (1999:27), penelitian kuantitatif lebih berdasarkan pada data angka untuk dapat menghasilkan penaksiran yang kokoh. Peneliti mengaplikasikannya dengan mengangkakan (scoring) pernyataan yang memerlukan alternatif jawaban melalui skala likert.

\section{HASIL DAN PEMBAHASAN}

Jadi hipotesis pada penelitian ini adalah sebagai berikut :

Ho1 $=0 \rightarrow \quad$ Tidak terdapat pengaruh dari point of purchase $(\mathrm{X})$ terhadap keputusan pembelian tidak terencana (Y).

$\mathrm{Ha} 1 \neq 0 \rightarrow \quad$ Terdapat pengaruh dari point of purchase (X) terhadap keputusan pembelian tidak terencana (Y).

Ho2 $=0 \rightarrow$ Tidak terdapat pengaruh dari in store media (X1) terhadap keputusan pembelian tidak terencana $(\mathrm{Y})$.

$\mathrm{Ha} 2 \neq 0 \rightarrow \quad$ Terdapat pengaruh dari in store media (X1) terhadap keputusan pembelian tidak terencana $(\mathrm{Y})$.

Ho3 $=0 \rightarrow$ Tidak terdapat pengaruh dari display (X2) terhadap keputusan pembelian tidak terencana $(\mathrm{Y})$.

Ha3 $\neq 0 \rightarrow \quad$ Terdapat pengaruh dari display (X2) terhadap keputusan pembelian tidak terencana $(\mathrm{Y})$.

Ho4 $=0 \rightarrow$ Tidak terdapat pengaruh dari signage (X3) terhadap keputusan pembelian tidak terencana (Y).

$\mathrm{Ha} 4 \neq 0 \rightarrow \quad$ Terdapat pengaruh dari signage (X3) terhadap keputusan pembelian tidak terencana $(\mathrm{Y})$.

\section{Populasi dan Sampel}

Dalam penelitian ini karakteristik populasi yang akan dijadikan sasaran adalah pengunjung di Carrefour Tamini Square. Populasi yang akan digunakan adalah jumlah pengunjung Carrefour Tamini Square selama sehari yang kira-kira sekitar 12000 orang.

\section{Pembahasan}

Atribut - atribut kuesioner yang ditanyakan kepada responden terlebih dahulu dilakukan pengujian berupa uji validitas dan uji reliabilitas. Dalam uji validitas dengan SPSS, semua atribut yang ditanyakan dalam kuesioner dinyatakan valid. Sedangkan dalam uji reliabilitas mendapatkan nilai Cronbach's Alpha sebesar 0,965. Menurut Nugroho (2005), kuesioner termasuk kedalam kategori sangat reliabel. 


\begin{tabular}{|c|c|c|c|c|c|c|}
\hline \multicolumn{7}{|c|}{ ANOVA $^{a}$} \\
\hline \multicolumn{2}{|c|}{ Model } & $\begin{array}{l}\text { Sum of } \\
\text { Squares }\end{array}$ & df & Mean Square & $\mathrm{F}$ & Sig. \\
\hline \multirow[t]{3}{*}{1} & Regression & 54,527 & 3 & 18,176 & 65,910 &, $000^{b}$ \\
\hline & Residual & 26,473 & 96 &, 276 & & \\
\hline & Total & 81,000 & 99 & & & \\
\hline
\end{tabular}

a. Dependent Variable: Pengambilan Keputusan

b. Predictors: (Constant), Display, In Store Media, Signage

Berdasarkan tabel Anova didapatkan nilai Sig. $=0.000<0.05$ dan F hitung $(65,910)>\mathrm{F}$ tabel $(2,70)$. Artinya point of purchase (Display, In Store Media, dan Signage) berpengaruh secara signifikan terhadap keputusan pembelian tidak terencana.

Hasil ini dapat dimaknai bahwa point of purchase dapat mempengaruhi keputusan pembelian tidak terencana. Semakin baik point of purchase, dalam penelitian ini in store media, signage, dan display yang diterapkan akan berdampak positif terhadap keputusan pembelian tidak terencana. Artinya semakin banyak konsumen yang memutuskan untuk membeli tanpa perencanaan terlebih dahulu dalam melakukan proses pembelian. Begitu pula sebaliknya, semakin buruk point of purchase, dalam penelitian ini in store media, signage, dan display yang diterapkan akan berdampak negatif terhadap keputusan pembelian tidak terencana. Artinya, jika Carrefour Tamini Square tidak memerhatikan kinerja point of purchase, maka akan sedikit konsumen yang memutuskan untuk membeli tanpa perencanaan ketika melakukan proses pembelian. Tapi ketika Carrefour Tamini Square memerhatikan kinerja point of purchase, makan semakin banyak konsumen yang tertarik dengan yang ditawarkan dan melakukan pembelian tidak terencana.

Untuk melihat seberapa besar pengaruh dari point of purchase terhadap keputusan pembelian tidak terencana, maka akan dilakukan analisis lanjutan dengan melihat koefisien determinasi. Koefisien determinasi berfungsi untuk mengetahui berapa persen pengaruh yang diberikan variabel bebas (X) secara simultan terhadap variabel terikat $(\mathrm{Y})$.

Dari output penelitian diperoleh koefisien determinasi sebesar 0.673 yang mengandung pengertian bahwa pengaruh variabel bebas (Display, In Store Media, dan Signage) terhadap variabel terikat (Keputusan Pembelian Tidak Terencana) adalah sebesar 67.3 persen (kuat). Angka ini menjelaskan bahwa keputusan pembelian tidak terencana mampu dipengaruhi secara kuat oleh variabel point of purchase sebesar 67.3 persen. Sementara itu, 32.7 persen sisanya dijelaskan oleh faktor-faktor lain yang tidak dijadikan variabel dalam penelitian ini. 


\begin{tabular}{|c|c|c|c|c|c|c|}
\hline \multicolumn{7}{|c|}{ Coefficients $^{a}$} \\
\hline \multirow[b]{2}{*}{ Model } & & \multicolumn{2}{|c|}{ Unstandardized Coefficients } & \multirow{2}{*}{$\begin{array}{c}\text { Standardized } \\
\text { Coefficients } \\
\text { Beta }\end{array}$} & \multirow[b]{2}{*}{$t$} & \multirow[b]{2}{*}{ Sig. } \\
\hline & & $B$ & Std. Error & & & \\
\hline \multirow[t]{4}{*}{1} & (Constant) & 1,375 &, 762 & & 1,805 & .074 \\
\hline & In Store Media &,- 008 &, 010 &,- 055 &,- 781 &, 437 \\
\hline & Signage &, 250 &, 019 & 1,196 & 13,060 &, 000 \\
\hline & Display &,- 289 & 037 &,- 676 & $-7,904$ &, 000 \\
\hline
\end{tabular}

a. Dependent Variable: Pengambilan Keputusan

Jika melihat tabel Coefficients, maka dapat diperoleh rumus regresi berganda sebagai berikut,

$\mathrm{Y}=\mathrm{a}+\mathrm{b}_{1} \mathrm{X}_{1}+\mathrm{b}_{2} \mathrm{X}_{2}+\mathrm{b}_{3} \mathrm{X}_{3}+\mathrm{e}$

$\mathrm{Y}=1.375-0.008 \mathrm{X}_{1}+0.250 \mathrm{X}_{2}-0.289 \mathrm{X}_{3}+\mathrm{e}$

Berdasarkan tabel Coefficients, yang mempunyai nilai Sig. $<0.05$ adalah dimensi Signage dan Display, masing-masing memiliki nilai Sig. $=0.00$, sedangkan In Store Media mempunyai nilai Sig. 0.437 yang artinya Sig. > 0.05. Artinya, dimensi point of purchase yang berpengaruh signifikan terhadap keputusan pembelian tidak terencana adalah Signage dan Display. Sementara dimensi In Store Media tidak berpengaruh signifikan terhadap keputusan pembelian tidak terencana.

Hasil perhitungan diatas didukung oleh perilaku konsumen yang selalu tertarik dengan promosi. Signage sebagai media promosi yang mudah terlihat, memberikan dampak signifikan terhadap keputusan pembelian tidak terencana. Atribut-atribut yang diuji dalam dimensi Signage adalah poster yang terpasang, desain poster, label harga yang terlihat jelas dan gampang dilihat, papan promosi, dan papan petunjuk yang menarik dan ada disetiap sudut tempat berdampak positif terhadap keputusan pembelian tidak terencana. Jika Signage dibuat semakin banyak dan semakin menarik perhatian, akan timbul dorongan untuk membeli pada diri konsumen karena semakin sering melihat promosi yang ada, maka keputusan untuk membeli secara tidak terencana akan semakin meningkat. Sebaliknya, jika Signage dibuat tidak menarik dan jumlahnya sedikit, konsumen tidak akan merasakan dorongan untuk melakukan pembelian, maka keputusan untuk membeli secara tidak terencana akan semakin menurun.

Jika melihat nilai koefisien terstandarisasi untuk interior display dan eksterior display adalah sebesar 0.289 dan bertanda negatif, ini menunjukkan bahwa display mempunyai pengaruh yang berlawanan terhadap keputusan pembelian tidak terencana konsumen. Artinya, semakin banyak produk yang di tampilkan (display) akan semakin menurun keputusan pembelian tidak terencana. Karena banyaknya produk yang ditampilkan, konsentrasi konsumen untuk memilih suatu produk akan buyar. Hal ini disebabkan oleh 
banyaknya informasi yang didapatkan oleh konsumen atas banyaknya pilihan produk. Karena pada kenyataannya tidak semua konsumen mengetahui bagaimana cara untuk memenuhi kebutuhannya atau tidak menyadari adanya produk yang mampu memenuhi kebutuhannya. Ketika konsumen mulai aktif mencari informasi tersebut, dan produk yang ditampilkan hanya sedikit pilihan, maka akan timbul dorongan pada diri konsumen untuk membeli produk tersebut. Saat pilihan yang dihadapkan sedikit, kemungkinan akan timbul keputusan untuk membeli tanpa direncanakan terlebih dahulu.

In store media ternyata tidak berpengaruh secara signifikan terhadap keputusan pembelian tidak terencana di Carrefour Tamini Square. Hal ini didasari oleh perilaku konsumen saat sedang melakukan proses pembelian yang ternyata lebih memerhatikan produk yang akan dibelinya dibanding hal-hal yang ada disekitarnya seperti video yang sedang terputar ataupun musik yang dimainkan. Beberapa atribut seperti musik, video, dan siaran dalam toko bagi sebagian konsumen dianggap mengganggu karena terlalu bising atau ramai, sehingga hal-hal tersebut cenderung diabaikan oleh konsumen.

\section{SIMPULAN}

Point of purchase mempunyai pengaruh terhadap keputusan pembelian tidak terencana secara simultan atau bersama-sama dengan kuat. Sebagian besar keputusan pembelian tidak terencana mampu dipengaruhi oleh variabel point of purchase. Sementara itu, masih ada hal-hal lain yang juga mempengaruhi sebagian kecil keputusan pembelian tidak terencana seperti advertising, sales promotion, event sponsorship, product placement, branded entertainment, direct marketing, personal selling, public relation, influencer marketing, corporate advertising, social media, dan word of mouth, yang juga dapat memberikan pengaruh terhadap seorang konsumen untuk melakukan pembelian yang tidak direncanakan sebelumnya dalam proses pembelian.

Secara parsial, singage mempunyai pengaruh terhadap keputusan pembelian tidak terencana. Hal ini didukung oleh perilaku konsumen yang selalu tertarik dengan promosi. Signage sebagai media promosi yang mudah terlihat, memberikan dampak signifikan terhadap keputusan pembelian tidak terencana.

Display mempunyai pengaruh yang berlawanan terhadap keputusan pembelian tidak terencana konsumen. Karena banyaknya produk yang ditampilkan, konsentrasi konsumen untuk memilih suatu produk akan buyar. Hal ini disebabkan oleh banyaknya informasi yang didapatkan oleh konsumen atas banyaknya pilihan produk. Karena pada kenyataannya tidak semua konsumen mengetahui bagaimana cara untuk memenuhi kebutuhannya atau tidak menyadari adanya produk yang mampu memenuhi kebutuhannya. Ketika konsumen mulai aktif mencari informasi tersebut, dan produk yang ditampilkan hanya sedikit pilihan, maka akan timbul dorongan pada diri konsumen 
untuk membeli produk tersebut. Saat pilihan yang dihadapkan sedikit, maka akan timbul keputusan untuk membeli tanpa direncanakan terlebih dahulu.

Dimensi in store media tidak mempunyai pengaruh yang signifikan terhadap keputusan pembelian tidak terencana. Hal ini didasari oleh perilaku konsumen saat sedang melakukan proses pembelian yang ternyata lebih memerhatikan produk yang akan dibelinya dibanding hal-hal yang ada disekitarnya seperti video yang sedang terputar ataupun musik yang dimainkan.

Jadi, dapat dikatakan bahwa point of purchase mempunyai pengaruh yang kuat terhadap keputusan pembelian tidak terencana secara simultan atau bersama-sama. Sedangkan secara parsial, hanya dimensi signage dan display yang mempunyai pengaruh terhadap keputusan pembelian tidak terencana. Sementara dimensi in store media tidak mempunyai pengaruh yang signifikan terhadap keputusan pembelian tidak terencana.

Berdasarkan hasil penelitian, terdapat saran untuk Carrefour Tamini Square yaitu : (1) Carrefour Tamini Square sebaiknya meningkatkan kualitas signage, karena hal tersebut adalah dimensi point of purchase yang berpengaruh terhadap keputusan pembelian tidak terencana. (2) Carrefour Tamini Square harus membuat display yang mengikuti trend saat ini, atau display tematik dengan konsep yang berbeda dan cenderung aneh atau unik, karena semakin aneh dan unik sebuah display, maka akan semakin menimbulkan rasa penasaran konsumen yang bisa berakhir dengan pembelian yang tidak direncanakan sebelumnya. (3) Carrefour Tamini Square dapat mengkaji ulang in store media dengan mempertimbangkan kebiasaan konsumen, sehingga dimensi tersebut bisa mempengaruhi keputusan konsumen untuk melakukan pembelian tidak terencana. (4) Carrefour Tamini Square bisa menyebar angket per periode untuk mengetahui apa yang bisa membuat konsumen memutuskan untuk membeli sesuatu dengan tidak terencana dan diaplikasikan ke dalam dimensi-dimensi point of purchase.

\section{DAFTAR PUSTAKA}

Kasali R. (1992), Manajemen Periklanan: Konsep dan Aplikasinya di Indonesia, Pustaka Utama Grafiti, Jakarta.

Kennedy, Soemanegara. (2006), Marketing Communication Taktik dan Strategi, Bhuana Ilmu Populer, Jakarta.

Kotler P, Amstrong G. (2001), Prinsip-prinsip Pemasaran, Jilid 2, Erlangga, Jakarta.

Kotler P, Keller KL. (2009), Manajemen Pemasaran, Edisi Ketiga Belas, Jilid I, Bob Sabran, penerjemah, Erlangga, Jakarta. 
Keller, K. L., Kotler, P., \& Manceau, D. (2016). Marketing Management (15e ed.). England: Pearson Education Limited.

Mangkunegara AP. (2012), Perilaku Konsumen, Refika Aditama, Bandung.

Mowen J, Minor M. (2002), Perilaku Konsumen, Jilid 1, Edisi Kelima, Lina Salim, penerjemah, Erlangga, Jakarta.

Mowen J, Minor M. (2002), Perilaku Konsumen, Jilid 2, Edisi Kelima, Dwi Kartini, penerjemah, Erlangga, Jakarta.

Schiffman L, Kanuk LL. (2008), Perilaku Konsumen, Edisi Ketujuh, Indeks, Jakarta.

Semenik, dkk. (2012), Advertising and Promotions: An Integrated Brand Approach, Sixth Edition, International Edition, Thomson - South Western, USA.

Shimp T. (2003), Periklanan Promosi Dan Aspek Tambahan Komunikasi Pemasaran Terpadu, Edisi Kelima, Jilid 1, Revyani Sahrial \& Dyah Anikasari, penerjemah, Erlangga, Jakarta.

Bahasa, A. Periklanan Promosi dan Aspek Tambahan Komunikasi Pemasaran Terpadu, edisi ke-5, Terjemahan: Reyvani Syahrial. Jakarta: Erlangga.

Sopiah, Syihabudin. (2008), Manajemen Bisnis Ritel, Andi, Yogyakarta.

Sugiyono. (2009) Metode Penelitian Bisnis (Pendekatan Kuantitatif, Kualitatif, dan R\&D), Alfabeta, Bandung.

Sumarwan U. (2011), Perilaku Konsumen Teori dan Penerapannya dalam Pemasaran, Ghalia Indonesia, Bogor.

Umar H. (1999), Riset Strategi Perusahaan, Gramedia Pustaka Utama, Jakarta. 